\title{
Consumer decision making
}

\section{a research note}

\author{
Hansen, Torben
}

Document Version

Final published version

Publication date:

2003

License

CC BY-NC-ND

Citation for published version (APA):

Hansen, T. (2003). Consumer decision making: a research note.

Link to publication in CBS Research Portal

\section{General rights}

Copyright and moral rights for the publications made accessible in the public portal are retained by the authors and/or other copyright owners and it is a condition of accessing publications that users recognise and abide by the legal requirements associated with these rights.

Take down policy

If you believe that this document breaches copyright please contact us (research.lib@cbs.dk) providing details, and we will remove access to the work immediately and investigate your claim. 


\section{Consumer Decision Making: A Research Note}

By

Torben Hansen ${ }^{1}$.

\footnotetext{
${ }^{1}$ Associate Professor, Ph.D., Department of Marketing, Copenhagen Business School, Solbjerg Plads 3, 2000 Frederiksberg, Denmark.

Tel.: + 45381521 00; Fax: + 45381521 01; E-mail: th.marktg@.cbs.dk
} 


\begin{abstract}
In the consumer behaviour literature several perspectives on consumer decision making have been considered, including the 'value perspective', the 'information processing perspective', the 'emotional perspective', and 'cue utilization theory'. In this paper, a framework which integrates several perspectives on consumer decision making and which hypothesizes possible links between several basic constructs is developed. The framework is tested by the use of two experimental designs. The results of this study support the complexity of consumer decision making: (A) Consumers do not use their cognitive and affective skills independently, rather they affect each other; (B) the cognitive, evaluative constructs of quality and attitude had significant direct effects on buying intention in both experiments, whereas the affective construct of emotion had no significant effects on buying intention in both experiments; (C) price affected in both experiments perceived quality, which in turn affected attitude, which in turn affected buying intention. At the same time, price had no direct effect on buying intention.
\end{abstract}




\section{INTRODUCTION}

Consumer decision making is often complicated and may involve a number of constructs. Several perspectives on consumer decision making have been considered in the literature. Some researchers have suggested that consumers are 'value-driven' (e.g., Zeithaml, 1988; Levy, 1999). A consumer's perceived value may be seen as an expression of "an overall assessment of the utility of a product (or service) based on perceptions of what is received and what is given" (Zeithaml, 1988, p. 14). Other researchers (e.g., Celsi \& Olson, 1988; Petty \& Cacioppo, 1983, 1986; Blackwell et al., 2001) have emphasized the role of involvement in explaining how likely consumers are to process e.g. cognitive information (Swinyard, 1993) and to engage in extensive evaluations of attributes and products. Low involved consumers may use simple decision rules in arriving at attitudinal judgments. For instance, according to 'cue utilization theory’ (e.g., Steenkamp, 1989; Richardson et al., 1994) consumers may simply use one or more indicators (e.g. price) of the quality or the overall performance of a product. The behaviour of high involved consumers may be analyzed and described on the basis of the information processing perspective. According to the information processing perspective (e.g., Østergaard \& Jantzen, 2000; Blackwell et al., 2001) the interaction between the consumer and stimuli in the environment is an ongoing cognitive process in which the consumer develops beliefs and attitudes towards the environment. The information processing perspective presupposes that the consumer, in order to avoid cognitive dissonance, seeks an equilibrium in which there is balance between the consumer's attitudes and beliefs and the actual environment (refer to Østergaard \& Jantzen, 2000). In contrast to the information processing perspective, other researchers (e.g. Holbrook and Hirschman, 1982; Holbrook \& Batra, 1987; Bagozzi, 1999) propose that consumer affections like emotional responses should be included in the explanation of consumer decision making. The consumer looks for 
new experiences via consumption. In this connection, the primary purpose is not to evaluate relations between attitude, beliefs, and the environment, but to fulfill a desire and to obtain pleasure in life.

The various perspectives on consumer decision making differ on several important dimensions. The value-perspective emphasizes situations in which consumers make value trade-offs, such as price versus quality in purchasing a food product. The construction of such trade-offs may, however, be difficult and may involve uncertainties. For example, the consumer does not always have a clear picture of the quality of a food product that is offered in a supermarket. This problem of uncertainty is not explicitly dealt with within the valueperspective, which does not include suggestions on how consumers will reduce the risk that follows from not knowing the outcome (e.g., the quality of a food product) or the negative consequences (e.g., will a low quality food product harm my health?) of carrying out a certain decision. Cue utilization theory, on the other hand, suggests that consumers may try to reduce risk by using cues (e.g., price, brand name, advertising, color, etc.) as indicators of the quality of a product or service. Thus, the reliance of one or more cues is one risk reduction strategy. Based on an extensive literature review Dawar \& Parker (1994) conclude that cues mostly serve as heuristics in assessing product quality when (among other factors) there is a need to reduce the perceived risk of purchase and when consumer involvement is low. From an information processing perspective a product can be conceived as an array of cues (Steenkamp, 1989), where cues can be regarded as 'pieces of information'. When the consumer is highly involved in the decision making he or she can be expected to engage in a more extensive internal and/or external information search for the purpose of reducing the risk of making a 'wrong' choice. Thus, such a consumer will have a high degree of cognitive 
activity and will make strong efforts in conducting evaluations and comparisons of products reaching for a reasoned decision. As in the value perspective (in which a perceived poor quality can be 'compensated' by a low price) consumers can make 'trade-offs' between various attributes (compensatory decision making) or the consumer can decide that one or more attribute must be represented in the product on a certain level (non-compensatory decision making). However, from an emotional perspective consumers do not make cognitive (compensatory or non-compensatory) evaluations when considering purchasing a product. Emotions should not be regarded as the result of an evaluation procedure but as an affective response to consumers' perceptions of stimuli in the environment (Bagozzi et al., 1999).

\section{Purpose of study}

Although the various perspectives on consumer decision making differ on several dimensions (including risk reduction strategies, the degree of cognitive and affective activity, and the construction of trade-offs and evaluations) the perspectives are also complementary. Consumers often use combinations of decision making strategies (refer to e.g. Bettman et al., 1998). For example, a consumer may eliminate a product alternative because of the product's country-of-origin if the consumer believes that the country is offering low quality alternatives within the considered product category (cue utilization theory). Or a consumer may simply like a product because it elicits positive emotions when the consumer looks at the product (emotional perspective). Such a positive emotion may directly affect the consumer's purchase behavior (Kotler, 1974; Babin and Darden, 1996) or may limit the number of alternatives for which more information (information processing perspective) is searched. Another consumer might assess trade-offs (value perspective) for a number of product alternatives, and then uses these trade-offs as input to a product comparison procedure (information processing 
perspective). Several writers have recognized that no single perspective offers the 'correct' theory on consumer decision making but that consumer research may benefit from a multiple perspective on decision making. Shiv and Fedorikhin (1999) propose that consumer researchers should take into account that consumer decision making can often be characterized as an interplay between cognition and affect: "the characterization of the consumer in previous decision-making research as a 'thinking machine', driven purely by cognitions, is a poor reflection of reality", p. 290. Foxall (1993) even suggests that "the present challenge for marketing researchers is to generate critical interpretations that alternate with the prevailing normal science component of consumer research: the notion that the information processing procedures of computers provide the key to understanding human choice" (p. 46). Also, as advocated by Weber et al. (1998) decision makers utilize multiple modes of decision making such as decision based on reasons, affect, cost-benefit calculation, and so on. Following such suggestions and considerations we propose a conceptual framework for understanding and integrating aspects of various (both cognitive and affective) perspectives on consumer decision making. Based on the framework the purposes of this paper are: (1) to review perspectives on consumer decision making with reference to the framework, and (2) to conduct empirical investigations in order to test the framework.

The paper is organized as follows. First, the conceptual framework is developed and research hypotheses are established. Then, an experimental research design is developed. Next, the obtained results are presented. Then, we discuss the theoretical and managerial implications of the study. Finally, the limitations of the present study are considered. 


\section{A CONCEPTUAL FRAMEWORK AND HYPOTHESES}

Several attempts have been made to develop models that seek to incorporate the possible complexity of consumer decision making. One often-cited model is the "consumer decision process model' (CDP-model; refer to Blackwell et al., 2001), which has been regularly updated since its first version was published in 1968. In the CDP model consumer decision making is seen as a problem solving task involving five key steps (need recognition, search, evaluation, purchase and post-purchase evaluation). The CDP model has strong emphasis on cognitive phenomena, particularly information processing and memory factors (refer to Dubois, 2000). It has even been criticised for being 'too cognitive' (Ehrenberg, 1988) and it is not very appropriate to describe situations in which consumers react emotionally or situations in which behavior can be regarded as a response to cues in the purchase situation. The 'five step sequence' in the CDP model is rather similar to the well-known 'Howard and Sheth model' (1969), which also can be considered as a cognitive model. The Howard and Sheth model is very comprehensive and is primarily used as a frame of reference to generate hypotheses about consumer behavior and consumer decision making rather than to predict specific behavior (refer to Dubois, 2000).

The theory of reasoned action (Fishbein \& Ajzen, 1975) and the theory of planned behavior (Ajzen, 1985) also reflect attempts to model consumer decision making. Although these models have been applied in a large number of studies (refer to e.g., Sheppard et al., 1988; Ajzen, 1991; Chang, 1998) non-evaluative components (emotional perspective) are not included in the models. Zeithaml (1988) has developed a model, which links internal (e.g., colour, ingredients) and external (e.g., price, advertising) product characteristics to perceived consequences (quality, value). The perceived consequences then affect buying intention. 
Zeithaml's model can be seen as an attempt to combine cue utilization theory with 'the value perspective' into a means-end model. However, the model does not explain how consumers' level of involvement may moderate the decision process (as proposed in the information perspective) or how consumers may respond emotionally to features of the decision making situation (emotional perspective).

Although several perspectives on consumer decision making have been considered in the consumer behavior literature it is also clear that only few attempts (e.g., Zeithaml, 1988) have been made to combine various perspectives into a conceptual model. Thus, reflecting the suggestions made by several researchers (e.g., Weber et al., 1998) that consumers utilize multiple modes of decision making, we hypothesize a framework which draws upon an array of theoretical perspectives on consumer decision making (i.e., the value perspective, cue utilization theory, the information processing perspective, and the emotional perspective). The hypothesized framework is displayed in Figure 1. The framework proposes possible links between several basic constructs related to consumer decision making: consumer involvement, consumer perception of price and quality, emotional response, attitude, and purchase intention.

\section{INSERT FIGURE 1 ABOUT HERE}

The hypothesized framework differs from established decision making models (e.g., CDP model, Howard and Sheth model, theory of reasoned action, theory of planned behavior, and the Zeithaml model) in various ways. The framework hypothesizes linkages between various individual-oriented constructs derived from different perspectives on consumer behaviour and 
decision making. Some of these linkages (e.g. the link between involvement and emotion) are not very often included in decision making models known to us. Also, we included both a non-evaluative affective component (emotional response) and an evaluative affective component (the affective component of attitude) in the framework. Thus, the conceptual framework is a 'hybrid' model representing various perspectives on consumer decision making. Of course, it can be argued that the model does not offer these perspectives a fair treatment as only aspects of the various perspectives are represented in the model. However, this does not prevent significant relationships from stepping forward when they occur. For example, one may argue that consumer emotion only represents one out of many possible affections, and that other consumer affections like enjoyment, fantasies, etc. should be included when seeking to understand consumer affections. Hence, we do not claim that the framework represents a comprehensive model of consumer decision making. Instead, it represents an attempt to add to our understanding of (theoretical derived) relations between important constructs within the field of consumer decision making. In the following the proposed links (hypotheses) included in the framework are discussed. In the discussion we link the proposed links to the theoretical perspectives from which they are derived.

\section{The Value Perspective}

Harnett (1998) believes that suppliers capable of offering the consumers 'great value' will be stronger in competition with other suppliers. In principle, the value emerges partly on what the consumer perceives s/he receives, partly on what the consumer perceives $\mathrm{s} / \mathrm{he}$ gives. The perhaps most common use of the value term relates to the trade-off between quality and price, which may also be termed the 'value-for-money' perspective (e.g., Chang and Wildt, 1994; Monroe, 1990; Abott, 1955; Hansen, 2001a; Sweeney and Soutar, 2001). From the individual 
consumer's point of view, the use of the value term means that it is possible to compare different values of product opportunities, and thereby also the individual product's ability to satisfy the consumer (Reeves and Bednar, 1994; Teas and Agarwal, 2000). In order to receive something, e.g. a product, the consumer must accept a use of certain resources. However, monetary (and other) resources are limited. The consumer must therefore try to direct her/his use of resources at the product offering the highest quality per used resource unit in the eyes of the consumer. It can therefore be expected that a consumer will prefer a low price to a high price and high quality to low quality. This does not deter some consumers from preferring one particular value package, e.g. the combination of high quality and high price, while others may prefer a value package consisting of the combination of poor quality and low price. Furthermore, some consumers will emphasize price over quality, while others, in turn, will emphasize quality more than price (Zeithaml, 1988). When planning whether to buy a product, consumers can be expected to consider positive as well as negative aspects (refer to e.g., Dubois, 2000). Hence, we hypothesize that:

H1: Perceived price is negatively related to buying intention

$\mathrm{H} 2$ : Perceived quality is positively related to buying intention

\section{Cue Utilization Theory}

Consumers are frequently faced with judging the quality of various products, when determing what to buy, in what amount. It may, however, be difficult for consumers to assess the importance of various quality-aspects in relation to each other and in relation to requirements rooted in the intended use of the products (SOU, 1994). Therefore, consumers are often faced with uncertainty when making judgments of the quality of products. However, the consumer 
may neither have the time nor the motivation to engage in extensive comparisons of the considered products. According to ‘cue utilization theory’ (Olson \& Jacoby, 1972;

Richardson et al., 1994) consumers may try to overcome their uncertainty and the lack of information by selecting one or more indicators (cues/stimuli) as a basis for their assessment of the quality of the product. An overwhelming amount of research on cue utilization theory has revealed a number of cues, which may be used by consumers as indicators of quality, including ‘country-of-origin' (Eliot \& Cameron, 1994; Peterson \& Jolibert, 1995), 'product composition' (Olson, 1972), 'brand name’ (Dodds, 1991), ‘store name’ (Dodds, 1991; Dodds, 1995), and 'price' (Leavitt, 1954; Shapiro, 1973; Brooker et al., 1986). From an economic point of view, there are at least two possible reasons for an expected positive correlation between price and quality. One is cost (quality costs money; consequently the quality of expensive products will be better). The second is demand (consumers demand quality; consequently quality products will be in greater demand, which will push prices up). The price of a product serves therefore at least to functions: (1) a higher price may signal higher quality (the 'positive' function of price), (2) the price denotes the sacrifice the consumer must make to obtain the product (the 'negative' function of price) (Zeithaml, 1988). While cue utilization theory can be seen as representing the 'positive' function of price, the value perspective can be seen as representing the 'negative' function of price. According to cue utilization theory, consumers may perceive a high price as an indicator of high quality (the positive function of price). Hence, we hypothesize as follows:

H3: Perceived price is positively related to perceived quality 


\section{The Information Processing Perspective}

The information perspective emphasizes that consumers have limitations on their capacity for processing information. These limitations include limited working memory and limited computational capabilities (Hansen, 1972; Bettman et al., 1998). Since the consumer's processing capacity is limited, the consumer cannot process high amounts of cognitive information in relation to all choice situations. According to the information perspective, a high involved consumer is more likely to process a high amount of cognitive information. Celsi \& Olson (1988) conceptualize involvement as "like most consumer researchers, we view perceived personal relevance as the essential characteristic of involvement” (p. 211). Consumers may be involved in buying a product for various reasons and different consumers may not be involved for the same reason. Consumers may purchase perfume because of its capacity to give pleasure, whereas consumers are more likely to focus on avoiding negative consequences of a bad choice when buying a vacuum cleaner (Laurent \& Kapferer, 1985). In

general, evidence from involvement research suggests, however, that factors such as high price, high perceived risk, high product heterogeneity, etc. are likely to increase the degree of consumer involvement (refer to e.g., Antil, 1983; Zaichkowsky, 1985; Rossiter \& Percy, 1987). Thus, it is hypothesized that:

H4: Perceived price is positively related to involvement

The information processing perspective presupposes that consumers behave as problem solving cognitive individuals reaching for a reasoned decision (Kassarjian, 1981). The 'Hierarchy of Effects' model (Lavidge and Steiner, 1961; Blackwell et al., 2001) suggests that a stimuli is first processed at its most basic level and then at more abstract levels (Dubois, 
2000). Consumers are expected to use their cognitive resources in forming beliefs (cognitive component) toward the attributes of a product, which in turn may result in the development of an overall feeling (affective component) in the sense of liking/disliking a product. Consumers with a positive attitude toward a product are expected to be more willing to consider buying it (conative component), than consumers with a less positive attitude toward the same product. In connection hereto, perceived quality can be regarded as a less abstract concept than attitude (refer to Grunert, 1996). Hence, perceived quality should be expected to precede attitude formation which in turn should be expected to precede buying intention in the consumer decision making process. We therefore hypothesize the following:

H5: Perceived quality is positively related to attitude

H6: Attitude is positively related to buying intention

\section{The Emotional Perspective}

The concepts of perceived quality and attitude can be seen as representing a cognitive (or instrumental, Alderson, 1957) view on consumer behaviour, in the sense that they both can be seen as the result of an evaluation procedure (Steenkamp, 1989). In contrast, emotions represent an affective view on consumer behaviour. Emotions are caused by consumers' exposure to specific stimuli. Surprise (an emotion) may for instance be caused by an unexpected gift (Derbaix and Pham, 1991). Several researchers (e.g., Zajonc \& Markus, 1982; Holbrook and Hirschman, 1982; Batra and Ray, 1986) have suggested that the 'traditional' cognitive view should be complemented with taking into account consumers' affections like the possible emotional responses to the perception and judgment of products and of consumption experiences. Consumer feelings have been shown to have several significant 
effects. Positive feelings can make one kinder, more generous, more resistant to temptation, and more willing to delay self-rewards (refer to Swinyard, 1993 for an overview). Also, previous research (Isen et al., 1978; Srull, 1983) suggests that individuals in positive-mood states evaluate stimuli more positively than individuals in neutral- or negative-mood states. Thus, we propose the following hypothesis:

H7: Emotion is positively related to attitude

Several researchers (e.g., Frijda, 1986; Bergenwall, 1998) link consumer emotion to consumer action. Bergenwall (1998) suggests that "emotions usually lead to some kind of actions by the individual, i.e. they have some kind of consequences" (p. 14). As an example, the experience of a rude employee of a service company may lead to some internal reactions, e.g. 'displeasure' (affect). These internal reactions may lead to complaining actions by the consumer (Bergenwall, 1998). In line with this view Zajonc (1980) and Zajonc \& Markus (1982) suggest that an individual can take action based on an emotional feeling, that is without or with just a low level of cognitive activity. Also, within the field of retailing research it is well established that retailers manipulate the physical environment to create specific emotional reactions among customers. The reason is that positive emotions seem to positively affect consumer purchase behaviour (Kotler, 1974; Barbin \& Darden, 1996). Swinyard (1993) found, however, no support for the hypothesis that consumers in a good mood will have more positive shopping intentions than those in a bad mood. However, Bagozzi et al. (1999) maintain that "emotions have implications for action and for goal attainment" (p. 186). Based on such considerations, we hypothesize that: 
H8: Emotion is positively related to buying intention

As involvement increases consumers' processing effort can be expected to increase. Since emotion is self-related high involved consumers may process more emotion information than low involved consumers (Swinyard, 1993). Peter et al. (1999) argue, "involvement...includes affect such as product evaluations (I like the taste of Magnum ice cream). If product involvement is high, people may experience stronger affective responses such as emotions and strong feelings" (p. 77). Additionally, people seem to like to be involved in making purchase decisions when purchase involvement (Mittal, 1989) is based on positive motivations (reaching for a more desirable state) rather than negative motivations (problem removal) (refer to Rossiter \& Percy, 1987). Such premises lead us to propose the following hypothesis (when purchase involvement is not negatively motivated):

H9: Purchase involvement is positively related to emotion

Perceived quality and emotions are related concepts in the sense that they both represent possible outcomes of consumers' exposure to stimuli in the environment. However, while perceived quality forms part of the cognitive system, emotions are part of consumers' affective system. The relationship between affect and cognition remains and issue in psychology and in consumer behaviour (refer to Peter \& Olson, 1996). Peter \& Olson argue that "it is more useful to emphasize the interaction between the affective and the cognitive systems than to argue about which system is more important or dominant" (p. 55). In accordance with this suggestion a link between perceived quality and emotion is argued. Emotions are based on the appraisals (i.e., consciously or unconsciously judgment and 
interpretation of stimuli; Bagozzi et al., 1999) consumers make to stimuli in the environment. A consumer who perceives a product to be of 'good quality' may form an affective response to this appraisal. That is, it is of course not the product itself that may produce an emotional response, but the consumer's perception of the product. Since consumers seem to prefer good quality to poor quality (e.g., Steenkamp, 1989; Hansen \& Solgaard, 2001; Hansen, 2002) it is therefore likely that the perception of good quality could cause consumer to produce a positive emotional response. Thus, it is hypothesized that:

H10: Perceived quality is positively related to emotion

A short note about 'emotion' versus 'mood' may be appropriate. According to Bagozzi et al. (1999) the main distinctions between mood and emotions are that mood is longer lasting and lower in intensity than emotion. Also, emotions are typical intentional (it has an object or referant), whereas moods are generally non-intentional. In addition, mood is not as directly coupled with action tendencies as emotion. This paper deals with emotion. Especially, we are interested in the positive/negative emotions, which may occur as a result of consumers being exposed to stimuli in the environment. Previous research (e.g., Watson \& Tellegan, 1985; Holbrook \& Batra, 1987; Mehrabian \& Russell, 1974) indicates that such emotions may be rather well captured by the concept of 'pleasure'. 


\section{EXPERIMENTAL DESIGN}

\section{Design}

Two 2 (high/low involvement) x 2 (high/low price) between subjects experimental designs were carried out to test and validate the hypotheses. Subjects were a total of 320 graduate students from the Copenhagen region. The products tested were fresh-shelled shrimps (experiment I) and solid cheese (experiment II). Two criteria guided the selection of the food products: (1) The products are often offered in supermarkets, specialty food stores, etc. without any brand attached to the products. We wished to avoid well known brands in the experiments since respondents may already have gained experiences towards such brands and may therefore 'know' the performance of the products in advance (Andrews \& Valenzi, 1971; Render \& O'Connor, 1976; Dodds, 1991). (2) The products should differ in terms of their perceived 'luxuriousness' to take into account the possible effect of the food product chosen on emotion. In Denmark (the country in which the experiments were carried out), the chosen type of shrimps are typically considered to be a more luxurious product than the chosen type of cheese (refer to Hansen, 2001b). The level of involvement was manipulated by setting two different buying purposes (refer to e.g., Antil, 1983; Ratchford, 1987). Low involvement (LI): Buying shrimps/cheese for daily purposes. High involvement (HI): Buying shrimps/cheese for guest purposes. The two types of buying purposes can be assumed to reflect 'neutral motivations' (buying for daily purposes, which can be regarded as an 'out of stock' situation) and 'positive motivations' (buying for guest purposes, e.g. the buyer may seek to enjoy the product and/or may seek personal recognition through the use of the product), respectively (Rossiter \& Percy, 1987; Hansen, 2001b). The price-level was manipulated by setting a low price and a high price, respectively. 


\section{Procedure}

One at the time subjects were welcomed and were guided to a neutral room containing two chairs, one table, and one dish containing the shrimps or the cheese. Experiment I: The 160 subjects participating in experiment I were asked to imagine that they intended to buy shrimps for an everyday dinner ( 80 subjects) or for a dinner party with guests ( 80 subjects), respectively. In each of the two groups of 80 subjects, half of the subjects were additionally exposed for a price sign displaying a low price, whereas the other half of the subjects were exposed for a price sign displaying a high price. Experiment II: The 160 subjects participating in experiment II were asked to imagine that they intended to buy cheese for an everyday breakfast ( 80 subjects) or for a dinner party with guests ( 80 subjects), respectively. Also, in each of the two groups, half of the subjects were exposed for a price sign displaying a low price, and the other half of the subjects were exposed for a price sign displaying a high price.

\section{Variable Measurement and Manipulation Checks}

Involvement: The manipulations of the intended purpose of usage were measured and checked by Mittal's (1989) Purchase Involvement Scale. If the manipulations had succeeded it should be expected that subjects who were asked to buy shrimps or cheese for guest purposes would score higher on the involvement scale compared to subjects who were asked to buy for daily purposes. A one-sided group means t-test resulted in a t-value of -2.190 ( $p$-value $=0.015)$ for shrimps, and a t-value of $-1.742(p$-value $=0.042)$ for cheese. Both these results indicate that the manipulations of the task-variable were perceived by subjects as intended.

Price-level: At the end of the experiments price-manipulations were measured by exposing subjects to the following statements: (1) "Compared to the average marketprice of 
shrimps/cheese the price of these shrimps/this cheese is in my opinion”. Scale end-points were 'much lower' and 'much higher', respectively. (2) 'In my opinion the price of these shrimps/this cheese is". Scale-end points were 'very low' and 'very high', respectively. A one-sided group means t-test for subjects exposed to low and high prices, respectively, resulted in a t-value of $-5.292(\mathrm{p}$-value $<0.001)$ for shrimps, and a t-value of -9.732 (p-value $<0.001)$ for cheese. The 'low price' was in both experiments perceived to be just below marketprice (3.83, shrimps; 3.18 , cheese) on the semantic scale concerning statement (1), while the 'high price' in both experiments was perceived to be just above average marketprice (4.93, shrimps; 4.84, cheese). Hence, it can be assumed that the manipulations of price are within the consumers acceptable price range (Gabor \& Granger, 1966).

Perceived quality: Perceived quality was measured using a 7-point Likert scale in combination with a 7-point semantic scale (refer to Steenkamp, 1989). The Likert scale measured the subject's level of agreement to the following statement: "These shrimps/this cheese are/is of good quality", while the semantic scale measured subjects response to the following statement: "Compared to the average quality of shrimps/cheese, the quality of these shrimps/this cheese are/is". The end-points of the semantic scale were 'much worser' and 'much better', respectively.

Emotion: Consumer research has produced a number of scales for the measuring of consumer emotions, among these Izard's (1977) Differential Emotions Scale (DES) which includes ten emotional emotions (interest, enjoyment, surprise, distress, anger, disgust, contempt, fear, shame/shyness, and guilt) and Mehrabian and Russel's (1974) PAD-Scale which includes three, more general emotional dimensions: pleasure, arousal, and dominance. In the present study the pleasure-dimension of Mehrabian and Russel's PAD-Scale was used to represent 
emotions. The pleasure-dimension of the PAD-can be described as: "pleasure is a feeling state that can be assessed readily with self-report, such as semantic differential measures, or with behavioural indicators such as smiles, laughter, and, in general, positive versus negative facial expressions" (pp. 18-19).

Attitude: Attitude was measured using a 7-point Likert scale in combination with a 7-point semantic scale. The Likert scale measured the subject's level of agreement to the following statement: "I find these shrimps/this cheese very attractive", while the semantic scale measured subjects response to the following statement: "Compared to shrimps/cheese in general, I find these shrimps/this cheese to be". The end-points of the semantic scale were 'much less attractive' and 'much more attractive', respectively.

Buying intention: Buying intention was measured by obtaining the respondents response to the following statement: "In your opinion, how likely is it that you would buy these shrimps/this cheese at some time in the near future?" Answers were given on a 7-point semantic scale ranging from 'totally unlikely' to 'most likely'.

\section{RESULTS}

\section{Initial Model Considerations}

The conducting of an exploratory factor analysis showed that the hypothesized discrimination between variables was generally maintained in both experiments. Also, all relevant factor loadings were significant $(\mathrm{p}<0.001)$. These initial model considerations indicate that the variables do exist and that they are tapped by the measures used. 


\section{Model Specification}

The model in Figure 1 was translated into a LISREL model consisting of a measurement part (confirmatory factor analysis) and a structural equation part (simultaneous linear regression). The relationships between the variables were estimated by maximum likelihood estimation.

\section{Measurement Model}

The results of the measurement model, including the standardized factor loadings, construct reliabilities, and proportion of extracted variance, are displayed in Table 1.

\section{INSERT TABLE 1 ABOUT HERE}

All factor loadings were significant $(\mathrm{p}<0.01)$ which demonstrate that the chosen generic questions for each latent variable reflect a single underlying construct. The reliabilities and variance extracted for each variable indicate that the model was reliable and valid. With the exception of one case, construct reliabilities exceed 0.6 (Bagozzi and Yi, 1988). Variance extracted estimates were all above 0.4 with the exception of one case. The reliabilities and variance were computed using indicator standardized loadings and measurement errors (Hair et al., 1998; Shim et al., 2000).

\section{Overall Model Fit}

We used three types of fit measures to assess the overall fit of the model. (1) Absolute fit measures: The chi square statistic was 112.3 (d.f. $=81, \mathrm{p}=0.012$ ) for experiment I and 119.7 (d.f. $=81, \mathrm{p}=0.003$ ) for experiment II. In both experiments the $\mathrm{p}$-value is below 0.05 indicating that the model in both cases fails to fit in an absolute sense. However, several writers (e.g., Hair et al., 1998) recommend that the chi-square measure should be 
complemented with other goodness-of-fit measures. The values of the goodness of fit index (GFI) were 0.941 (experiment I) and 0.935 (experiment II), which in both cases are well above the acceptable level of 0.9 (Bollen and Long, 1993) indicating a good overall model fit. The point estimates of RMSEA were 0.050 (experiment I) and 0.049 (experiment II), which in both experiments indicate a close fit of the model in relation to the degrees of freedom (Bollen and Long, 1993). (2) Incremental fit measures: The incremental fit measures provide support to the model. The adjusted goodness of fit index (AGFI) showed values at 0.923 (experiment I) and 0.921 (experiment II) which both are above the threshold of 0.9. In addition, the Tucker-Lewis index amount to 0.992 for experiment I and 0.991 for experiment II, and the Bentler and Bonett normed fit index gave the following values: 0.983 (experiment I) and 0.981 (experiment II). All these values exceed the suggested 0.9 threshold, which indicates that the improvement of fit over the null model is substantial (Dröge, 1989). (3) Parsimonious fit measures: One measure applicable for evaluating a single model is the normed chi-square measure (Hair et al., 1998). The computed values of 1.39 (experiment I) and 1.48 (experiment II) fall within the proposed threshold limits for this measure (Jöreskog, 1970; Carmines and McIver, 1981). To conclude, support is provided for the overall model as proposed.

\section{Results}

The estimates of the structural equation coefficients and the p-values are displayed in Table 2.

\section{INSERT TABLE 2 ABOUT HERE}

Most of the hypothesized relationships were confirmed in the experiments. On the basis of cue utilization theory it was proposed that price had a positive significant effect on perceived 
quality. This proposition was confirmed in both experiments. (The regression weights of 0.60 and 0.41 had both $p$-values $<0.01$ ). The suggestion derived from the value perspective that price would negatively affect buying intention could, however, not be confirmed in the experiments (regression weights were 0.12 , p-value $>0.10$; and -0.05 , $p$-value $>0.10$, respectively). The strength of the relationships between emotion and attitude and between emotion and buying intention suggest that emotion neither affect buying intention directly nor indirectly. However, emotion was positively affected by the level of involvement in both experiments (regression weights were 0.31 , p-value $<0.01$; and 0.23 , p-value $<0.05$, respectively) and by perceived quality (regression weights of 0.24 , p-value $<0.05$, and $0.46, p$ value $<0.01$, respectively). The main predicting elements of buying intention were quality (regression weights of 0.33 and $0.49 ; \mathrm{p}$-values $<0.01$ ) and attitude (regression weights of 0.39 and 0.43 ; p-values $<0.01)$. In experiment $\mathrm{I}$, the direct effect of quality on buying intention (regression weight of 0.33 , p-value $<0.01$ ) was much larger than the indirect effect on buying intention through attitude (indirect effect, experiment I: $0.35 \times 0.39=0.14$ ). However, in experiment II the indirect effect of quality on buying intention through attitude $(0.92 \mathrm{x}$ $0.43=0.40, \mathrm{p}$-value $<0.01$ ) was almost as high as the direct effect of quality on buying intention (regression weight of $0.49, \mathrm{p}$-value $<0.01$ ). Therefore, no general conclusion can be reached regarding whether the effect of quality on buying intention is primarily direct or indirect. Also, no general conclusion can be obtained regarding the effect of price on involvement level in the experiments. This effect was only significant in experiment II (regression weight of 0.29 , p-value $<0.05$ ). 


\section{DISCUSSION}

The results of this study support the complexity of consumer decision making. Consumers do not use their cognitive and affective skills independently, rather they affect each other. Hence, perceived quality was in both experiments found to significantly affect consumer emotion. This result supports the notion made by Bagozzi et al. (1999) that emotions are based on the appraisals consumers make to stimuli in the environment. Respondents who have made a positive appraisal to the manipulated food product (i.e., perceived the food product to be of good quality) had a more positive response (higher pleasure-feeling) than respondents who had made less positive appraisals to the manipulated food product. The result also suggests that food consumption is not just a matter of getting nutrients but that food consumption is a psychological (cognitive-affective) matter too (refer to French et al., 1994). We like food products of perceived high quality. In addition, involvement, which in the applied measurement scale was treated as a cognitive construct, had a significant effect on consumer emotion in both experiments. This result indicates that people like to be involved when involvement is based on positive motivations like buying shrimps or cheese for guest purposes.

The results also indicate that the respondents did evaluate the manipulated food products. For example, price affected in both experiments perceived quality, which in turn affected attitude, which in turn affected buying intention. At the same time, price had no direct effect on buying intention. Thus, price had only an indirect effect on buying intention through the evaluative constructs of perceived quality and attitude. However, this result may also reflect that the respondents were exposed to 'unknown' food products with no brand or other cues attached to them with the exception of the manipulated price-level. That is, the respondents might have 
been uncertain on how to determine the quality of the manipulated food products and might therefore have looked for additional information (i.e. in this connection the manipulated price) as it is proposed in cue utilization theory. In other incidents, in which the decision process may be routinized or habitual, the consumer may simply choose a well-known brand. It can even be argued that some proportion of consumer choice does not involve consumer decision making, not even on the first purchase (Olshavsky \& Granbois, 1979). The cognitive, evaluative constructs of quality and attitude had significant direct effects on buying intention in both experiments, whereas the affective construct of emotion had no significant effects on buying intention in both experiments. Hence, the obtained results indicate that consumers are more inclined to buy standard and luxurious food products on the basis of cognitive thinking than on the basis of an emotional response, which in the present case is represented by pleasure-feeling. A group means t-test supports that both a luxurious food product and a standard food product were used in the experiments as pleasure-feeling was significantly higher for respondents exposed to shrimps than for respondents exposed to cheese $(\mathrm{p}<0.001)$.

The respondents used the manipulated price as a quality indicator in the experiments. This suggests that in general, the consumer keeps an open mind towards useful stimuli in the environment as it is presupposed in the information processing perspective. Consumer resources are, however, limited and the consumer may therefore seek to direct her/his use of resources at the information most easily available (Simonson, 1999) or at the information offering the greatest relevant knowledge per used resource unit in the eyes of the consumer. Previous research (Kunda, 1990) indicates that consumers might favour beliefs, which are in accordance with a preferred conclusion. Jain and Maheswaran (2000) found that consumers who have strongly held preferences counterargue preference-inconsistent information more 
than preference-consistent information. This finding suggests that consumers do not objectively process and integrate new information in their decision making process as it is assumed in the information processing perspective. Rather there is a resistance to devote resources to change already established preferences.

It was considered to hypothesize a link between involvement and perceived quality in the framework (refer to Figure 1). If consumers are positively motivated they may process more positive quality information than negative (refer to Swinyard, 1993) and may therefore be expected to perceive the quality of the manipulated food products in a more positive way. On the other hand, involved consumers may at the same time perceive the quality information in a more critical way to reduce the risk of making a bad choice. Because of such considerations we chosed not to link involvement with perceived quality in the framework. [An estimation of the effect of involvement on perceived quality showed very low regression weights $(0.02$, experiment I; 0.08, experiment II)].

\section{Suggestions for future research}

Much work remains to be done within this research area. There are many voids in our present knowledge of how different theoretical perspectives and constructs may complement each other in the consumer decision making process. Not enough is known about the interplay between the consumer's affective and cognitive skills. As an example, future research may examine other variables that may moderate the relationship between involvement and emotion or the relationship between quality and emotion. To what extent are these relations moderated by the circumstances under which the product is considered, by the type of product and/or by personal or cultural factors? Further research may also examine how various types of 
emotions (refer to e.g., Izard, 1977; Richins, 1997) may affect the cognitive-affective interplay. In addition, some consumers may be more sensitive to one or more of the constructs in the framework. As an example, some consumers are more likely to perceive risk than are others (Sweeney et al., 1999). Quality and attitude may play a higher role for such consumers since they may be less willing to accept the risk of getting a low quality product. Also, such consumers can be expected to be more involved in the purchase. Thus, further research may wish to estimate the framework for various consumer segments to investigate the sensitivity of the framework constructs.

One aspect which may even further complicate the analysis and the description of the consumer decision making process is the informational environment confronting consumers (King and Hill, 1994; Sheth et al., 2001). As stated by King and Hill, "today, consumers frequently find themselves faced with ill-structured selection tasks involving choices of new and complex products and services, and an environment in which available information is often abundant, but frequently disorganized and incomprehensible" (p. 181). Also, the increasingly shortened life cycle of many products, the increasing internationalisation and complexity as well as the emergence of the Internet are all examples of conditions that have contributed to the fact that the environment in which the consumer must plan and execute her/his behaviour has become increasingly complex. Perhaps this complexity means that consumers face increasing difficulties in generating firm and stable preferences for many products and that preferences therefore often will be highly context dependent. This means that consumers' approach to decision making may be sensitive to the local problem structure. As advocated by Bettman et al. (1998) this type of 'constructive choice processing' suggests that consumers do not apply one invariant approach to solve problems, consumers apply a 
variety of approaches, often developed in the particular choice situation. Hence, future research should investigate how different forms of choice complexity may affect consumer decision making.

\section{Practical implications}

Perhaps the most important implication of this research is that managers should cope intensively with investigating consumer decision making processes. Consumer decision making may be complex and may involve a number of various perspectives and constructs. Thus, management should continuously seek to develop its consumer behavior competence. As the environment is getting more complex such competence is (perhaps) needed more than ever before. The results of the present study suggest that consumers use price (positively) as an indicator of product quality. However, previous research indicates this relationship is not universally true. Depending on the product category (e.g., TV sets) price may even negatively affect perceived product quality (refer to Lee and Lou, 1996). For a particular product category, a company should therefore measure the strength of the price-perceived quality relationship. If a strong (significant) positive relationship is detected, a company may consider using price as a quality-positioning tool. Such a quality-positioning strategy is further supported by the result that quality in both experiments positively affected attitude and buying intention.

In both experiments, involvement and quality positively affected emotion but emotion did not affect attitude or buying intention. However, this does not mean that companies should not cope with the emotional state of their consumers. For example, Nyer (1997) has found that emotions (e.g., joy) affect postconsumption behaviors such as positive and negative word-of- 
mouth communication. Also, emotions have been found to be predictors of complaining behavior (Westbrook, 1987; Stephens and Gwinner, 1988). In relation hereto, companies should also focus on other factors (e.g., consumer personality, responses of other people), which may affect consumer emotions (Lazarus, 1991).

\section{LIMITATIONS}

This research concentrated on analysing two (food) products, fresh-shelled shrimps and solid cheese. This could mean that the results may suffer from a lack of generalizability. A large cross-section of products ought to be studied to improve the generalizability of the results. Also, the manipulation of price was confined to two different levels. Thus, this research offers no specific guidelines on how to set specific prices for the purpose of manipulating e.g. consumers' perceived quality. It may also be argued that the respondents were not randomly sampled from a 'true' population of consumers and that the results therefore suffer from a lack of external validity. However, it should be recalled that external validity can hardly be achieved in a single study (Derbaix and Pham, 1991). Also, Sternthal et al. (1994) argue that when one is interested in detecting causal relationships "a homogeneous sample [e.g., students] is the prefered option...this increases the likelihood that the causal relations of interest will be observed when they exist” (pp. 208-209). 


\section{REFERENCES}

Abbott, L. (1955), Quality and Competition, Columbia University Press, New York.

Ajzen, I. (1985), From Intentions to Actions: A Theory of Planned Behavior. In: J. Kuhland and J.

Beckman (eds.), Action-control: From Cognitions to Behvaior, Springer, Heidelberg, pp. 11-39.

Ajzen, I. (1991), The Theory of Planned Behavior, Organizational Behavior and Human Decision

Processes, 50, pp. 179-211.

Alderson, W. (1957), Marketing behavior and executive action, Homewood, IL: Irwin.

Andrews, I. R. \& E. R. Valenzi (1971), Combining price, brand, and store cues to form an impression of product quality, Proceedings of the $79^{\text {th }}$ annual Convention of the American Psychological Association, pp. 649-650.

Antil, J.H. (1983), Conceptualization and operationalization of Involvement, Advances in' Consumer Research, pp. 203-209.

Babin, B.J. and Darden, W.R. (1996), Good and Bad Shopping Vibes: Spending and Patronage Satisfaction, Journal of Business Research, 35, pp. 201-206.

Bagozzi, R.P. and Yi, Y. (1988), On the Evaluation of Structural Equation Models, Journal of the Academy of Marketing Science, Vol. 16, No. 1, pp. 74-94. 
Bagozzi, R.P., Gopinath, M., and Prashanth, U.N. (1999), The Role of Emotions in Marketing, Journal of the Academy of Marketing Science, Vol. 27, No. 2, pp. 184-206.

Batra, R. and Ray, M.L. (1986), Affective responses mediating acceptance of advertising, Journal of Consumer Research, 13, 234-249.

Bergenwall, M. (1998), An Overview of Emotion Theory: Incorporating the Concept of Emotion Into Service Quality Research, Meddelanden Working Papers, No. 367, Swedish School of Economics and Business Administration.

Bettman, J.R., Luce, M.F., and Payne, J.W. (1998), Constructive Consumer Choice Processes, Journal of Consumer Research, Vol. 25, December, pp. 187-217.

Blackwell, R.D., P.W. Miniard \& J.F. Engel (2001), Consumer Behavior, ninth edition, Harcourt.

Bollen, K.A. and J.S. Long (1993), Testing Structural Equation Models, London, SAGE Publications.

Brooker, G., Wheatley, J.J., and Chiu, J.S.Y. (1986), The effects of sampling and information on brand choice when beliefs in quality differences are ambiguous. In: R.J. Lutz (Ed.), Advances in Consumer Research, Vol. XIII, ACR, pp. 272-276.

Bollen, K.A. and J.S. Long (1993), Testing Structural Equation Models, London, SAGE Publications.

Carmines, E. and J. McIver (1981), Analyzing Models with Unobserved Variables: Analysis of Covariance Structures, in G. Bohrnstedt and E. Borgatta (Eds.), Social Measurement: Current Issues, Beverly Hills, Calif.: Sage. 
Celsi, R.L. and Olson, J.C. (1988), The role of involvement in attention and comprehension processess, Journal of Consumer Research, Vol. 15, pp. 210-224.

Chang, T-Z. and Wildt, A.R. (1994), Price, product information, and purchase intention: An empirical study, Journal of the Academy of Marketing Science, 22, pp. 16-27.

Chang, M.K. (1998), Predicting unethical behavior: A comparison of the theory of reasoned action on the theory of planned behavior, Journal of Business Ethics, Vol. 17 (16), pp. 1825-1834.

Derbaix, C. and Pham, M.T. (1991), Affective Reactions to Consumption Situations, Journal of Economic Psychology, Vol. 12, Iss. 2, pp. 325-355.

Dhar, R. and Wertenbroch, K. (2000), Consumer Choice Between Hedonic and Utilitarian Goods, Journal of Marketing Research, Vol. XXXVII, pp. 60-71.

Dodds, W.B. (1991), In search of value: How price and store name information influence buyers' product perceptions, Journal of Consumer Marketing, Vol. 28, pp. 307-319.

Dodds, W.B. (1995), Market cues affect on consumers' product evaluations, Journal of Marketing Theory \& Practice, Vol. 3, pp. 50-63.

Dröge, C. (1989), Shaping the Route to Attitude Change: Central Versus Peripheral Processing Through Comparative Versus Noncomparative Advertising, Journal of Marketing Research, Vol. XXVI (May), pp. 193-204.

Dubois, B. (2000), Understanding the Consumer, Prentice Hall. 
Ehrenberg, A. (1988), Repeat Buying: Theory and Applications, $2^{\text {nd }}$ edition, London: Griffin and Co.

Elliot, G.R. and Cameron, R.C. (1994), Consumer Perception of Product Quality and the Country-of Origin Effect, Journal of International Marketing, Vol. 2, No. 2, pp. 49-62.

Fishbein, M. and Ajzen, I. (1975), Belief, Attitude, Intention, and Behavior: An Introduction to Theory and Research, Addison Wesley, Reading Mass.

Frijda, N.H. (1986), The Emotions, Cambridge: Cambridge University Press.

Gabor, A. and Granger, C.W. (1966), Price as an indicator of quality: Report on an inquiry, Economica, 32, pp. 43-70.

Grunert, K.G. (1996), What's in a steak? A cross-cultural study on the quality perceptions of beef, MAPP working paper no. 39, Århus School of Business.

Hair, J.F., R.E. Anderson, R.L. Tatham, and W.C. Black (1998), Multivariate Data Analysis, Prentice Hall, Fifth Edition.

Hansen, F. (1972), Consumer Choice Behavior - A Cognitive Theory, The Free Press/ McMillan, New York \& London.

Hansen, T. (2001a), Quality in the Marketplace: A Theoretical and Empirical Investigation, European Management Journal, Vol. 19, pp. 203-211.

Hansen, T. (2001b), Fødevarekvalitet - et forbrugerperspektiv, Jurist- og Økonomforbundets Forlag, 1. udgave (in Danish). 
Hansen, T. and Solgaard. H.S. (2001), Food and consumer satisfaction: LISREL results from two Danish experiments, Journal of Food Products Marketing, Vol. 7-3, pp. 25-39.

Hansen, T. (2002), The Effect of Physical Surroundings in Usage Situations on Consumer Perception of Food Quality and on Consumer Emotions, Journal of International Consumer Marketing, Vol. 15, No. 1, pp. 31-52.

Harnett, M. (1998), Shopper Needs Must Be Priority, Discount Store News, 37, pp. 21-22.

Holbrook, M.B. and Hirschman, E.C. (1982), The experiental aspects of consumption: Consumer fantasies, feelings, and fun, Journal of Consumer Research, 9, pp. 132-140.

Holbrook, M.B. and Batra, R. (1987), Assessing the Role of Emotions as Mediators of Consumer Responses to Advertising, Journal of Consumer Research, 14, pp. 404-420.

Howard, J. and Sheth, J. (1968), A Theory of Buying Behavior, in H.H. Kassarjian and T.S. Robertson (eds.), Perspectives in Consumer Behavior (Scott, Foresman: 1968), pp. 467-487.

Isen, A.M., Shalker, T.E., Clark, M., and Karp, L. (1978), Affect, Accessibility of Material in Memory, and Behavior: A Cognitive Loop?, Journal of Personality and Social Psychology, 36(1), pp. $1-12$.

Izard, C.E. (1977), Human Emotions, New York: Plenum.

Jain, S.P. and Maheswaran, (2000), Motivated Reasoning: A Depth-of-Processing Perspective, Journal of Consumer Research, Vol. 26, pp. 358-371. 
Jensen, H.R. (2001), Antecedents and consequences of consumer value assessments: implications for marketing strategy and future research, Journal of Retailing and Consumer Services, 8, pp. 299-310.

Jöreskog, K.G. (1970), A General Method for Analysis of Covariance Structures, Biometrika, 57, pp. 239-251.

Kassarjian, H.H. (1981), Low Involvement: A Second Look. In: Advances in Consumer Research, Vol. 8, Kent Monroe and Ann Arbor (Ed.), ACR, pp. 31-33.

King, A.F. and Hill, D.J. (1994), Electronic Decision Aids: Integration of a Consumer Perspective, Journal of Consumer Policy, 17, pp. 181-206.

Kotler, P. (1974), Atmospherics as a Marketing Tool, Journal of Retailing, 49, pp. 48-64.

Kunda, Z. (1990), The Case for Motivated Reasoning, Psychological Bulletin, 108(3), pp. 480-498.

Lavidge, R. and Steiner, G.A. (1961), A Model For Predictive Measurements of Advertising, Journal of Marketing, October.

Laurent, G. and Kapferer, J.N. (1985), Measuring Consumer Involvement Profiles, Journal of Marketing Research, February, pp. 41-53.

Lazarus, R.S. (1991), Emotion and Adaptation, New York: Oxford University Press.

Leavitt, H.J. (1954), A note on some experimental findings about the meaning of price, Journal of Business, 27, pp. 205-210. 
Lee, M.L. (1996), Consumer Reliance on Intrinsic and Extrinsic Cues in Products Evaluations: A Conjoint Approach, Journal of Applied Business Research, Vol. 12, No. 1, pp. 21-27.

Levy, M. (1999), Revolutionizing the Retail Pricing Game, Discount Store News, 38, p. 15.

Mehrabian, A. and Russel, J.A. (1974), An Approach to Environmental Psychology, The MIT Press.

Mittal, B. (1989), Measuring Purchase-Decision Involvement, Psychology \& Marketing, Vol. 6, pp. $147-162$.

Monroe, K.B. (1990), Pricing: Making Profitable Decisions, second edition, McGraw-Hill: New York.

Nyer, P.U. (1997), A Study of the Relationships Between Cognitive Appraisals and Consumption Emotions, Journal of the Academy of Marketing Science, 25 (Fall), pp. 296-304.

Olshavsky, R.W. and Granbois, D.H. (1979), Consumer Decision Making - Fact or Fiction, Journal of Consumer Research, Vol. 6, pp. 93-100.

Olson, J.C. (1972), Cue Utilization in the quality perception process: A cognitive model and an empirical test, Unpublished doctoral dissertation, Purdue University, Indiana.

Olson, J.C. and Jacoby, J. (1972), Cue Utilization in the Quality Perception Process, In M. Venkatesan (Ed.), Proceedings of the Third Annual Conference of the Association for Consumer Research, Association for Consumer Research, pp. 167-179. 
Olson, J.C. and Reynolds, T.J. (1983), Understanding consumers' cognitive structures: implications for advertising strategy. In: Advertising and Consumer Psychology Vol. 1, (Eds.) Percy, L. and Woodside, A., Lexington Books, Lexington, MA.

Peter, J.P. and Olson, J.C. (1996), Consumer Behavior and Marketing Strategy, Irwin, $4^{\text {th }}$ Edition.

Peter, J.P, Olson, J.C., and Grunert, K.G. (1999), Consumer Behaviour and Marketing Strategy European Edition, McGraw Hill International (UK).

Peterson, R.A. and Jolibert, A.J.P. (1995), A meta-analysis of country-of-origin effects, Journal of International Business Studies, Vol. 26, pp. 883-900.

Petty, R.E., Cacioppo, J.T. Cacioppo, and Schumann, D. (1983), Central and Peripheral Routes to Advertising Effectiveness: The Moderating Role of Involvement, Journal of Consumer Research, Vol. 10, pp. 135-146.

Petty, R.E. and Cacioppo, J.T. (1986), The Elaboration Likelihood Model of Persuasion, Advances in Experimental Social Psychology, Vol. 19, pp. 123-205.

Ratchford, Brian T. (1987), New Insights About the FCB Grid, Journal of Advertisng Research, Vol. 27, pp. 24-37.

Reeves, C.A. and Bednar, D.A. (1994), Defining Quality: alternatives and implications, Academy of Management Review, Vol. 19, No. 3, pp. 419-445.

Render, B. and O'Connor, Th.S. (1976), The influence of price, store name, and brand name on perception of product quality, Journal of The Academy of Marketing Science, 4, pp. 722-730. 
Richardson, P.S., Dick, A.S., and Jain, A.K. (1994), Extrinsic and Intrinsic Cue Effects on Perceptions of Store Brand Quality, Journal of Marketing, Vol. 58, pp. 28-36.

Richins, M.L. (1997), Measuring Emotions in the Consumption Experience, Journal of Consumer Research, Vol. 24, pp. 127-146.

Rossiter, J.R. and Percy, L. (1987), Advertising and Promotion Management, McGraw-Hill.

Shapiro, B.P. (1973), Price reliance: Existence and sources, Journal of Marketing Research, 10, pp. 286-294.

Sheppard, B.H., Hartwick, J., and Warshaw, P.R. (1988), The Theory of Reasoned Action: A MetaAnalysis of Past Research with Recommendations for Modifications and Future Research, Journal of Consumer Research, Vol. 15, pp. 325-343.

Sheth, J.N., Eshghi, A., and Krishnan, B.C. (2001), Internet Marketing, Harcourt College Publishers, New York.

Shim, S., Eastlick, M.A., Lotz, S.L., and Warrington, P. (2001), An online prepurchase intentions model: The role of intention to search, Journal of Retailing, 77, pp. 397-416.

Shiv, B. and Fedorikhin, A. (1999), Heart and mind in conflict: The interplay of affect and cognition in consumer decision making, Journal of Consumer Research; Gainesville, Vol. 26, Iss. 3, pp. 278292. 
Simonson, I. (1999), The Effect of Product Assortiment on Buyer Preferences, Journal of Retailing, Vol. 75 (3), pp. 347-370.

SOU, Statens offentliga utredningar (1994), Konsumenterna och livsmedelskvaliteten - En studie av konsumentupplevelser, delbetänkande av Konsumentberedningen, Stockholm (in Swedish).

Srull, T.K. (1983), Affect and Memory: The Impact of Affective Reactions in Advertising on the Representation of Product Information in Memory. In: $A C R$. Vol. 10, (Eds.) R.P. Bagozzi and A. Tybout, pp. 520-525.

Steenkamp, J.B.E. M. (1989), Product Quality, Van Corcum, The Netherlands.

Steenkamp, J.B.E.M. \& Van Trijp, H.C.M. (1989), Quality guidence: A consumer-based approach for product quality improvement. In: Marketing Thought and Practice in the 1990s. (Eds.) G.J. Avlonitis, N.K. Papavasilliou \& A.G. Kouremenos, pp. 1191-1217.

Stephens, N. and Gwinner, K.P. (1998), Why Don't Some People Complain? A Cognitive-Emotive Process Model of Consumer Complaint Behavior, Journal of the Academy of Marketing Science, Vol. 26, No. 3, pp. 172-189.

Sternthal, B., Tybout, A.M., and Calder, B.J. (1994), Experimental Design: Generalization and Theoretical Explanation,. In: R.P. Bagozzi (Ed.), Principles of Marketing Research, Blackwell, pp. $195-223$.

Sweeney, J.C., Soutar, G.N., and Johnson, L.W. (1999), The Role of Perceived Risk in the QualityValue Relationship: A Study in a Retail Environment, Journal of Retailing, Vol. 75(1), pp. 77-105. 
Sweeney, J.C. and Soutar, G.N. (2001), Consumer perceived value: The development of a multiple item scale, Journal of Retailing, Volume 77, Issue 2, pp. 203-220.

Swinyard, W.R. (1993), The Effects of Mood, Involvement, and Quality of Store Experience on Shopping Intentions, Journal of Consumer Research, Vol. 20, pp. 271-280.

Teas, K.R. and Agarwal, S. (2000), The Effects of Intrisinc Product Cues on Consumers' Perceptions of Quality, Sacrifice, and Value, Journal of the Academy of Marketing Science, Vol. 28, No. 2 , pp. 278-290.

Watson, D. and Tellegan, A. (1985), Toward a Consensual Structure of Mood, Psychological Bulletin, 98, (September), pp. 219-235.

Weber, E.U., Blais, A-R., and Tada, Y. (1998), From Shakespeare to Spielberg: Predicitng Selection among Modes of Decision Making, paper presented at the expanded version of the presidential adress by Elke Weber, delivered at 1998 annual meeting of the Society for Judgment and Decision Making, Dallas.

Westbrook, R.A. (1987), Product/Consumption Based Affective Responses and Post Purchase Processes, Journal of Marketing Research 24 (August), pp. 258-270.

Zaichkowsky, J.L. (1985), Measuring the Involvement Construct, Journal of Consumer Research, 12, pp. 341-352.

Zajonc, R.B. (1980), Feeling and Thinking: Preferences Need no Inferences, American Psychologist, 35, pp. 151-175. 
Zajonc, R.B. and Markus, H. (1982), Affective and Cognitive Factors in Preferences, Journal of Consuemr Research, Vol. 9, September, pp. 123-131.

Zeithaml, V.A. (1988), Consumer Perceptions of Price, Quality and Value: A Means-End Model and Synthesis of Evidence, Journal of Marketing, Vol. 52, p. 2-22.

Østergaard, P. and Jantzen, C. (2000), Shifting Perspectives in Consumer Research: From Buyer Behavior to Consumption Studies. In: S.C. Beckmann and R.H. Elliot (Eds.), Interpretive Consumer Research-Paradigms, Methodologies \& Applications, Handelshøjskolens Forlag, Copenhagen, pp. 923. 


\section{FIGURES AND TABLES}

Figure 1. The Conceptual Framework

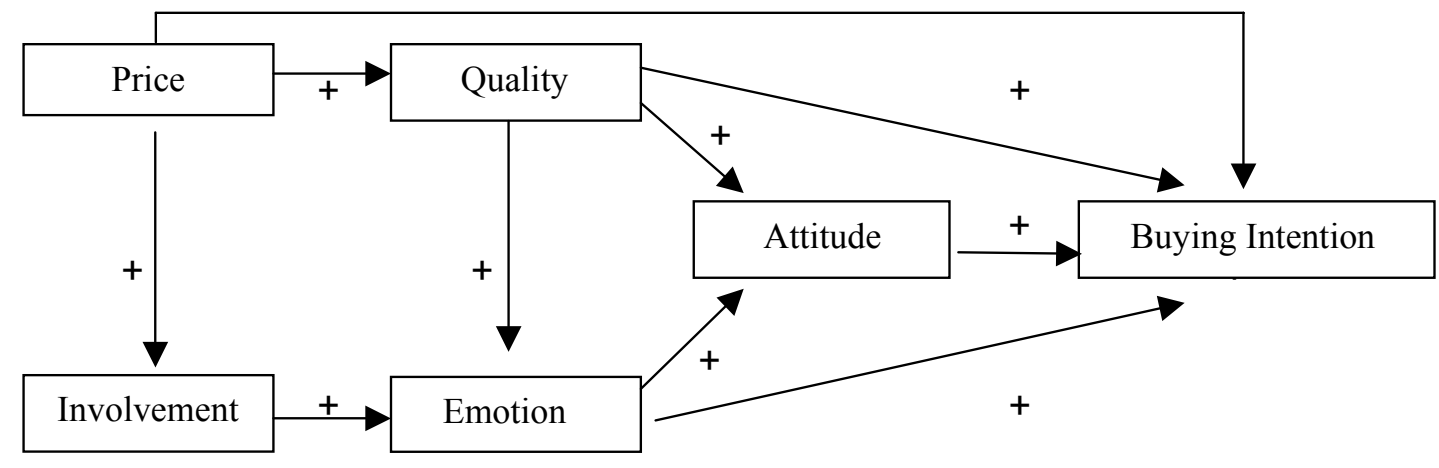


Table 1. Confirmatory Factor Analyses Results

\begin{tabular}{|c|c|c|c|c|c|c|}
\hline \multirow{2}{*}{$\begin{array}{l}\text { Construct/ } \\
\text { Indicator }\end{array}$} & \multicolumn{2}{|c|}{$\begin{array}{l}\text { Standardized } \\
\text { Factor Loading }\end{array}$} & \multicolumn{2}{|c|}{$\begin{array}{l}\text { Construct } \\
\text { Reliability }\end{array}$} & \multicolumn{2}{|c|}{$\begin{array}{l}\text { Extracted } \\
\text { Variance }\end{array}$} \\
\hline & Exp. I & Exp. II & Exp. I & Exp. II & Exp. I & Exp. II \\
\hline$\xi 1$ Price & & & 0.67 & 0.63 & 0.51 & 0.46 \\
\hline $\mathrm{X} 1$ & 0.65 & 0.62 & & & & \\
\hline $\mathrm{X} 2$ & 0.77 & 0.73 & & & & \\
\hline$\eta 1$ Involvement & & & 0.69 & 0.73 & 0.43 & 0.48 \\
\hline X3 & 0.73 & 0.54 & & & & \\
\hline $\mathrm{X} 4$ & 0.56 & 0.79 & & & & \\
\hline $\mathrm{X} 5$ & 0.67 & 0.73 & & & & \\
\hline १2 Quality & & & 0.68 & 0.67 & 0.53 & 0.53 \\
\hline X6 & 0.89 & 0.91 & & & & \\
\hline$X 7$ & 0.52 & 0.47 & & & & \\
\hline$\eta 3$ Emotion & & & 0.79 & 0.82 & 0.43 & 0.49 \\
\hline $\mathrm{X} 8$ & 0.60 & 0.73 & & & & \\
\hline X9 & 0.73 & 0.80 & & & & \\
\hline $\mathrm{X} 10$ & 0.55 & 0.53 & & & & \\
\hline X11 & 0.75 & 0.74 & & & & \\
\hline $\mathrm{X} 12$ & 0.64 & 0.66 & & & & \\
\hline १4 Attitude & & & 0.67 & 0.48 & 0.51 & 0.32 \\
\hline X13 & 0.76 & 0.62 & & & & \\
\hline X14 & 0.66 & 0.51 & & & & \\
\hline
\end{tabular}

Notes: Exp. I: Experiment I; Exp. II: Experiment II.

In relation to the measurements of involvement and emotion one item had in each of the constructs an item-total correlation $<0.3$ and was therefore excluded from the applied measurement scale.

Buying intention is measured by a single item and is therefore not displayed. 
Table 2

Estimation results for experiment I and II

(Standardized regression weights)

\begin{tabular}{lccl}
\hline & Estimates of structural equation coefficients & \\
Relations & Experiment I & Experiment II & Test results \\
\hline Price $\rightarrow$ Buying Intention (H1) & 0.12 & -0.05 & Rejected \\
Quality $\rightarrow$ Buying Intention (H2) & $0.33^{* *}$ & $0.49^{* *}$ & Accepted \\
Price $\rightarrow$ Quality (H3) & $0.60^{* *}$ & $0.41^{* *}$ & Accepted \\
Price $\rightarrow$ Involvement (H4) & -0.01 & $0.29^{*}$ & Reject/accept \\
Quality $\rightarrow$ Attitude(H5) & $0.35^{* *}$ & $0.92^{* *}$ & Accepted \\
Attitude $\rightarrow$ Buying Intention (H6) & $0.39^{* *}$ & $0.43^{* *}$ & Accepted \\
Emotion $\rightarrow$ Attitude (H7) & 0.16 & 0.17 & Rejected \\
Emotion $\rightarrow$ Buying Intention (H8) & 0.10 & 0.05 & Rejected \\
Involvement $\rightarrow$ Emotion (H9) & $0.31^{* *}$ & $0.23^{*}$ & Accepted \\
Quality $\rightarrow$ Emotion (H10) & $0.24^{*}$ & $0.46^{* *}$ & Accepted \\
**: Significant on 1\% level & & & \\
$*:$ Significant on 5\% level & & & \\
\hline
\end{tabular}

